\title{
Effect of the catalytic system and operating conditions on BTX formation using tetralin as a model molecule
}

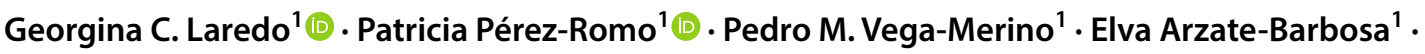 \\ Alfonso García-López ${ }^{1} \cdot$ Ricardo Agueda-Rangel ${ }^{1} \cdot$ Victor H. Martínez-Moreno ${ }^{1}[$
}

Received: 15 May 2019 / Accepted: 18 October 2019 / Published online: 1 November 2019

(c) The Author(s) 2019

\begin{abstract}
Light cycle oil (LCO) is an inexpensive feedstock for the production of high-added-commercial-value-mono-aromatic compounds such as benzene, toluene and xylenes (BTX). To extend the knowledge on the processing of LCO for BTX production, the hydrocracking reaction was studied using a commercial $\mathrm{NiMo} / \mathrm{Al}_{2} \mathrm{O}_{3}$ catalyst, ZSM-5 zeolite and their mechanical mixtures $\left(20 / 80,30 / 70\right.$ and 50/50) for processing tetralin as model feedstock in a bench-scale-trickle-bed reactor at $450-500{ }^{\circ} \mathrm{C}$, 3.9-5.9 MPa, $1.31 / \mathrm{h}$ and $\mathrm{H}_{2} /$ feed volume ratio of $168-267 \mathrm{~m}^{3} / \mathrm{m}^{3}$. Accessible, well-dispersed and strong Brönsted acid sites eased the hydrocracking of tetralin to BTX and the metallic hydrogenation functions from nickel-molybdenum catalysts were also required to minimize deactivation. To achieve suitable tetralin conversions (86-95 wt\%), high BTX selectivity in the liquid phase (44-70 wt \%) and suitable catalytic activities for coke precursor hydrogenation (to reduce deactivation), $\mathrm{NiMo} / \mathrm{Al}_{2} \mathrm{O}_{3} / / \mathrm{ZSM}-5$ mixtures (50-80 ZSM-5) were employed, which probed to be effective.
\end{abstract}

Keywords $\mathrm{BTX} \cdot$ Tetralin hydrocracking $\cdot \mathrm{LCO} \cdot \mathrm{NiMo} / \mathrm{Al}_{2} \mathrm{O}_{3} \cdot \mathrm{ZSM}-5$

\section{Introduction}

The increasing development of more environmentally friendly energy sources like those provided by the sun, hydrogen and biofuels has exerted a negative impact on the global demand for oil and natural gas for fuel manufacture,

Georgina C. Laredo

glaredo@imp.mx

Patricia Pérez-Romo

pperezr@imp.mx

Pedro M. Vega-Merino

pvega@imp.mx

Elva Arzate-Barbosa

earzate@imp.mx

Alfonso García-López

aglopez@imp.mx

Ricardo Agueda-Rangel

ragueda@imp.mx

Victor H. Martínez-Moreno

vhmartin@imp.mx

1 Instituto Mexicano del Petróleo, Eje Central Lázaro Cárdenas Norte 152, San Bartolo Atepehuacan, Gustavo A. Madero, 07740 Mexico City, Mexico moving the balance in the coming years toward the production of petrochemicals such as olefins and benzene, toluene and xylene (BTX). This change represents a huge challenge for the oil refining industry since a large group of chemicals still requires to be derived from oil and natural gas to comply with the sharply rising demand for goods and services. One of the streams produced by the fluid catalytic cracking (FCC) process that can be used as petrochemical feedstock is the light cycle oil (LCO). Approximately, one-third of the LCO production is currently processed in hydrodesulfurization units that produce low-sulfur diesel fuel, and the remnant is used as a diluent of fuel oil for electric power generation [21]. In this sense, Laredo et al. [14] reported that LCO may contain up to $4 \mathrm{wt} \%$ of sulfur, $1000 \mathrm{wtppm}$ of nitrogen and $75 \mathrm{wt} \%$ of aromatics, which shows that LCO has a limited usage to produce diesel fuel that can comply with the specifications from entities like the Environmental Protection Agency [9] and The European Automobile Manufacturers Association [10]. Notwithstanding, the high concentration of naphthalene derivatives (methyl-, dimethyl-, trimethyl- and tetramethyl-naphthalenes, Fig. 1) makes of LCO a suitable candidate, as an inexpensive feedstock, for the production of high-commercial-added-value-mono aromatics such as benzene, toluene and xylene (BTX). Such 
Fig. 1 Detailed GC-FID analysis of a typical LCO sample. In the figure, $\mathrm{C} 14$ to $\mathrm{C} 23$ and iC15 to iC23 represent linear alkanes and branched alkanes, respectively

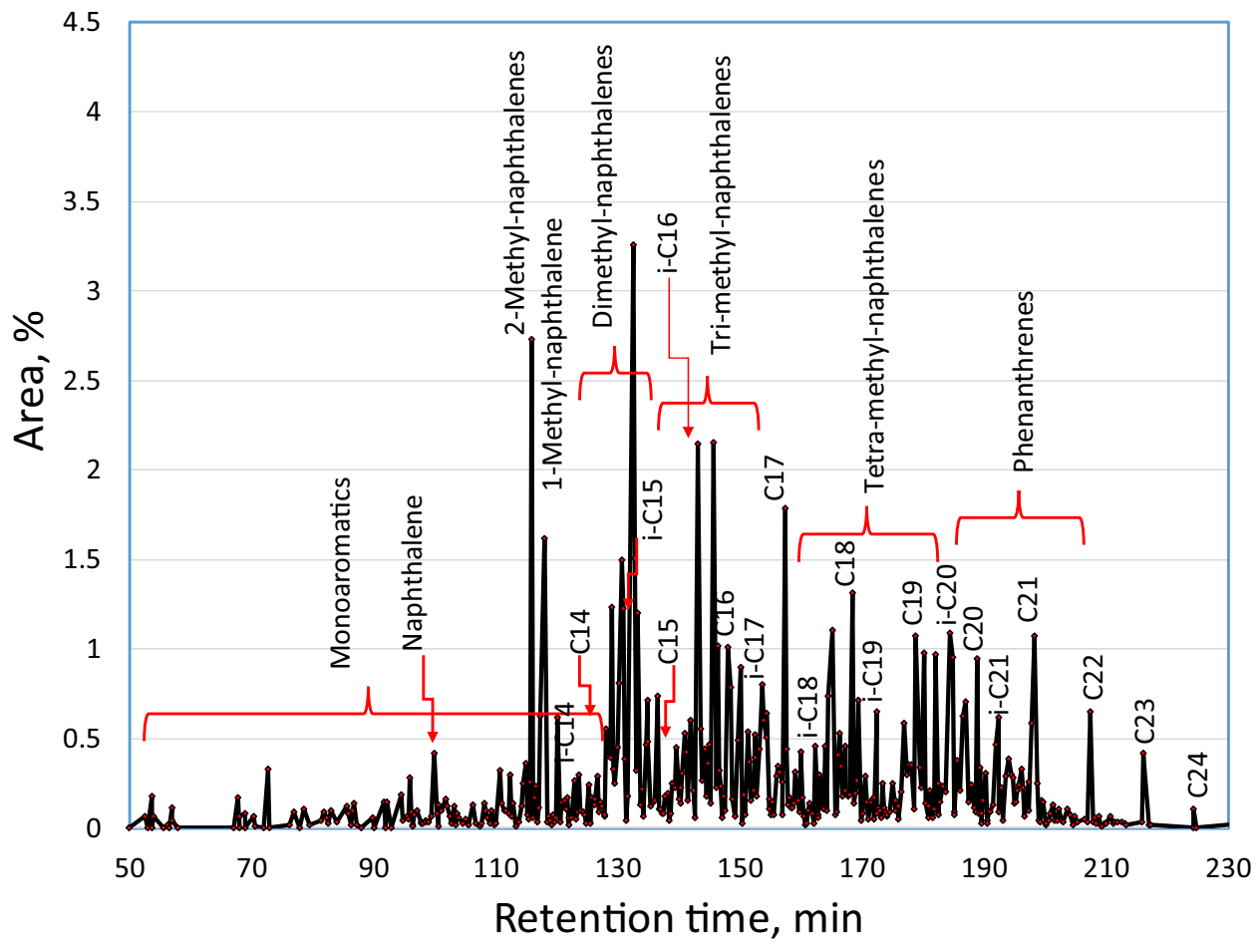

Naphthalene<smiles>CCOc1ccccc1</smiles>

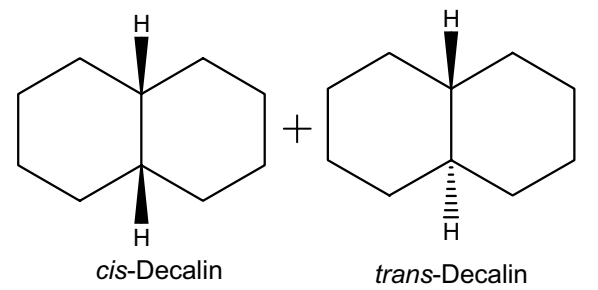

Hydrocracking

Fig. 2 Reaction scheme for the tetralin hydrocracking into BTX 
development involves hydrogenation (HYD) and hydrocracking (HYC) transformations (Fig. 2, with naphthalene as a model molecule) [15]. The HYD process not only produces tetralin isomers but also removes sulfur and nitrogen compounds present in real feedstocks, thus promoting the HYC of tetralin isomers into BTX [15]. Figure 2 also shows that tetralin isomers may undergo further hydrogenation, which leads to the formation of decalin isomers and these compounds can be hydrocracked into LPG and naphtha. The relatively complex tetralin conversion may involve aromatic ring hydrogenation, naphthenic ring isomerization (ring contraction), naphthenic ring opening, dealkylation, cracking reactions, disproportionation and transalkylation, which lead to many reaction products depending on the nature of the active sites present on the catalytic surface [19]. The tetralin reaction can be initiated by a bimolecular mechanism, which is responsible for the formation of phenylbutyl tetralin derivatives through a unimolecular mechanism, which involves the attack of a Brönsted site either on the aromatic ring or on the naphthenic ring [19].

On the other hand, zeolites have shown remarkable cracking properties associated with their acidic nature and topology [6]. More specifically, ZSM-5, in its hydrogen form, has Brönsted and Lewis acidity with acid $\mathrm{OH}$ groups at channel intersections. The presence of acid sites explains the cracking activity displayed by ZSM-5, which shows unique shapeselectivity properties due to the presence of medium-size pores $[16,20]$. In addition, the hydrogenation power of a metallic function is necessary to minimize excessive cracking and polymerization reactions that can poison the acid sites and finally can lead to catalyst deactivation $[15,19$, 20]. Thus, bi-functional catalysts combining both acidic and metallic functions are required.

As for this subject matter, Laredo et al. [15] published a review about the selective hydrocracking of tetralin using different materials, with and without metallic functionalities. Recently, Shin et al. [20] studied the design of a catalyst with the appropriate balance of hydrogenation and acidity characteristics for producing BTX from polycyclic aromatics present in diesel-boiling-range feedstocks like LCO. These scientists concluded that a suitable catalyst for a $54.3 \%$ BTX yield (theoretical maximum of $67.1 \%$ ) from tetralin could be synthesized by supporting nickel and molybdenum on a mechanical mixture of Beta and HZSM-5 zeolites with a 90/10 ratio when reacting at $425^{\circ} \mathrm{C}$.

In conclusion, a bi-functional catalyst is required to have both hydrogenation capacity for avoiding deactivation by carbon deposition $[12,13]$ and acidic functions for hydrocracking purposes $[15,20]$. Therefore, the hydrogenation capabilities of a metallic catalyst $\left(\mathrm{NiMo} / \mathrm{Al}_{2} \mathrm{O}_{3}\right)$ combined with the acidic function of a zeolitic material (ZSM-5) were used to study the tetralin hydrocracking for BTX production, focusing on the compromise between BTX selectivity and catalyst deactivation. In order to avoid the interference of the metal moieties on the acidic zeolite structure, as Sato et al. [18] reported, it was used a mechanical mixture of $\mathrm{NiMo} / \mathrm{Al}_{2} \mathrm{O}_{3}$ and ZSM-5. This mixture was chosen taking into account the adequate hydrogenation activity of the NiMo metals mixture and the acidic properties of the ZSM-5 zeolite, with high dealkylation activity [16, 20]. The study was carried out in a trickle-bed reactor at $450-500{ }^{\circ} \mathrm{C}$, 3.9-5.9 MPa, 1.3/h (liquid hourly space velocity, LHSV) and $117-267, \mathrm{H}_{2} /$ feed volume ratio $\mathrm{m}^{3} / \mathrm{m}^{3}$. It is expected that the results presented in this work may contribute to extend the knowledge on the LCO hydrocracking for BTX production.

\section{Experimental}

\section{Materials}

1,2,3,4-Tetrahydronaphthalene (tetralin) was purchased from Sigma Aldrich and used in the experiments without further purification. The commercial ZSM-5 (P/Z-2/25) was kindly supplied by Zeochem. The $\mathrm{NiMo} / \mathrm{Al}_{2} \mathrm{O}_{3}$ material was the commercial IMP-DSD3 by the Mexican Petroleum Institute (in Spanish: Instituto Mexicano del Petróleo, IMP).

Nitrogen adsorption-desorption isotherms and specific surface area for both materials were obtained at $77 \mathrm{~K}$ on a Micromeritics ASAP-2000 analyzer in accordance with the BET method. The acid sites of both materials were determined by FTIR-pyridine desorption using an FTIR spectrometer Thermo Nicolet model Magna 560. For the analysis, a pure-catalyst-made disk was treated under vacuum at $1.33 \times 10^{-3} \mathrm{~Pa}$ and $500{ }^{\circ} \mathrm{C}$ for $5 \mathrm{~h}$, which was then cooled down to room temperature and later treated with pyridine vapor and afterwards heated at $150{ }^{\circ} \mathrm{C}$ under high vacuum for $30 \mathrm{~min}$. IR spectra were collected at different temperatures, i.e., ambient temperature, $100,200,300$, and $400{ }^{\circ} \mathrm{C}$. The amount of Brönsted and Lewis acid sites was calculated via integration of the area of the absorption bands, showing maximum intensity values at 1450 and $1550 / \mathrm{cm}$, respectively. The integrated absorbance of each band was obtained by using the appropriate software (OMNIC) and applying the corresponding extinction coefficient, normalized by the weight of the samples. Details of these calculations have been reported by several authors $[3,8]$. The calibration of this method was performed periodically by using a faujasitetype zeolite (NIST 8850) as an external standard.

The NiMo/ $/ \mathrm{Al}_{2} \mathrm{O}_{3}$ metallic composition was obtained by elemental analysis, using a Perkin-Elmer Model 3100 Atomic Absorption Spectrophotometer (Table 1).

After the reaction, the sulfided $\mathrm{NiMo} / \mathrm{Al}_{2} \mathrm{O}_{3}$ catalyst was studied by high-resolution transmission electron microscopy (HRTEM). The micrographs were obtained in a Titan 80-300 with Schottky-type field emission gun operating at

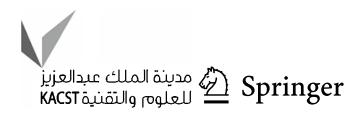


Table 1 Properties of the $\mathrm{NiMo} / \mathrm{Al}_{2} \mathrm{O}_{3}$ and ZSM-5 catalysts

\begin{tabular}{|c|c|c|c|c|}
\hline Form & & $\mathrm{NiMo} / \mathrm{Al}_{2} \mathrm{O}_{3}$ & & ZSM-5 \\
\hline \multicolumn{5}{|l|}{ Physical properties } \\
\hline $\mathrm{Si} / \mathrm{Al}$ & & & & 25 \\
\hline Density $\left(\mathrm{g} / \mathrm{cm}^{3}\right)$ & & $0.70-0.75$ & & $0.65-0.70$ \\
\hline Pore volume $\left(\mathrm{cm}^{3} / \mathrm{g}\right)$ & & $0.45-0.65$ & & \\
\hline Pore diameter (nm) & & 10.6 & & 0.636 \\
\hline Surface area $\left(\mathrm{m}^{2} / \mathrm{g}\right)$ & & $180-350$ & & \\
\hline \multicolumn{5}{|l|}{ Chemical properties } \\
\hline $\mathrm{Ni}(\mathrm{wt} \%)$ & & $2.30-4.5$ & & \\
\hline Mo (wt $\%)$ & & $10.0-20.0$ & & \\
\hline \multirow[t]{2}{*}{ Form } & \multicolumn{2}{|l|}{$\mathrm{NiMo} / \mathrm{Al}_{2} \mathrm{O}_{3}$} & \multicolumn{2}{|l|}{ ZSM-5 } \\
\hline & \multicolumn{2}{|l|}{ 3-mm extrudates } & \multicolumn{2}{|l|}{ 1-2-mm sphere } \\
\hline Acidity $(\mu \mathrm{mol} \mathrm{Py} / \mathrm{g})$ & Brönsted & $\overline{\text { Lewis }}$ & Brönsted & Lewis \\
\hline 100 & 54 & 337 & 173 & 176 \\
\hline 200 & 25 & 230 & 116 & 76 \\
\hline 300 & 10 & 138 & 52 & 38 \\
\hline 400 & 2 & 76 & 23 & 28 \\
\hline
\end{tabular}

$300 \mathrm{kV}$. The point resolution and information limit were better than $0.085 \mathrm{~nm}$. The HRTEM digital images were obtained using a CCD camera and Digital Micrograph Software from Gatan. In order to prepare the materials for observation, the powder samples were ultrasonically dispersed in ethanol and supported on holey-carbon-coated-copper grids.

Thermogravimetric analyses (TGA-DSC) using a Setsys 12 analyzer were performed for the measurement of the materials that covered the catalyst surface after the experiments were carried out after $144 \mathrm{~h}$ of time on stream (TOS). About $20 \mathrm{mg}$ of the catalyst sample was heated in the presence of a gas mixture containing $15 \% \mathrm{O}_{2}$ in $\mathrm{N}_{2}$ flowing at a rate of $60 \mathrm{~mL} / \mathrm{min}$. The mass loss was monitored as a function of temperature. A linear heating rate of $5{ }^{\circ} \mathrm{C} /$ min was used throughout the analyses up to $900{ }^{\circ} \mathrm{C}$. In the 200-600 ${ }^{\circ} \mathrm{C}$ interval, an exothermic event was detected, which corresponded to the combustion of organic agents in the catalyst $\left(W_{\mathrm{c}}\right)$.

\section{Testing methods}

Pellets of the NiMo/ $\mathrm{Al}_{2} \mathrm{O}_{3}$ catalyst and ZSM-5 zeolite (Table 1) were crushed, sieved to $40 / 60$ mesh, dried in an oven at $120^{\circ} \mathrm{C}$ for $2 \mathrm{~h}$ and then tested separately and mixed at 20/80, 30/70, and 50/50 catalyst/zeolite wt\% ratios. Experimental runs were carried out in a bench-scale unit equipped with a trickle-fixed-bed reactor (volume $=6.62 \mathrm{~mL}$; internal diameter $=1.0 \mathrm{~cm}$; down-flow mode; and isothermal axial profile) under the experimental conditions described in Tables 3 and 4 and Figs. 5, 6, 7 and 8. A total mass of
$5.0 \mathrm{~g}$ of solid was placed in the reactor. The catalysts were presulfided in situ for $18 \mathrm{~h}$ with desulfurized naphtha spiked with dimethyldisulfide (S: $1.5-2.5 \mathrm{wt} \%$ ) at $210-315{ }^{\circ} \mathrm{C}$, 4.0 MPa, 1.0/h (LHSV) and $\mathrm{H}_{2} /$ feed volume ratio of 315$378 \mathrm{~m}^{3} / \mathrm{m}^{3}$. Once the bench-scale unit was stabilized, reaching steady-state, the feed was changed to dimethyldisulfidedoped tetralin (S: $0.02 \mathrm{wt} \%$ ) to maintain the metallic catalyst in its sulfided form. The feed was run continuously for $24 \mathrm{~h}$; then, gas and liquid reaction products were collected every $8 \mathrm{~h}$ and analyzed according to the methods described in the next section and the obtained average values were used to estimate the catalytic performance for a given experimental point.

\section{Product characterization and calculations}

Complete mass balances of gas and liquids from the feed and products were recovered in a gas-liquid online separator under the different experimental conditions obtained after 24 and $144 \mathrm{~h}$ depending on the experiment carried out in the pilot plant. Gas and liquid fractions were obtained $\left(F_{\mathrm{G}}\right.$ and $F_{\mathrm{L}}$ ).

The gas fraction of the products was characterized by gas chromatography following the UOP539-12, Refinery Gas Analysis by GC. The feed and the liquid fraction of the products were characterized by a gas chromatography method as follows: a Bruker gas chromatograph equipped with flame ionization detector and auto-ignition system, which can operate at $400{ }^{\circ} \mathrm{C}$ as maximum temperature, $2 \mathrm{pg}{ }^{\circ} \mathrm{C} / \mathrm{s}$ (as selectivity index) and linear dynamic range of 
$10^{7}$, was used. The FID-GC presented the following set of columns: $105 \mathrm{~m}$ WCOT column (internal diameter: $320 \mu \mathrm{m}$ ), $50 \mathrm{~m}$ WCOT column (internal diameter: $320 \mu \mathrm{m}$ ), and $105 \mathrm{~m}$ WCOT column (internal diameter: $320 \mu \mathrm{m}$ ). The carrier gas was helium, which was fed at $3 \mathrm{~mL} / \mathrm{min}$. The temperature program was $40{ }^{\circ} \mathrm{C} \mathrm{(2-min} \mathrm{dwelling)} \mathrm{with} \mathrm{a} \mathrm{heating} \mathrm{ramp} \mathrm{of}$ $10{ }^{\circ} \mathrm{C} / \mathrm{min}$ to $300{ }^{\circ} \mathrm{C}$, and $2 \mathrm{~min}$ standing at this temperature as final condition. The detector and injector temperatures were 330 and $320^{\circ} \mathrm{C}$, respectively. The columns operated at constant gas flow at $0.0015 \mathrm{~Pa}$. The characterization of the hydrocarbons was performed by comparing the retention times of the sample with the average of the retention times

Table 2 Retention times of the different hydrocarbons using the GCFID method

\begin{tabular}{lll}
\hline Hydrocarbon & Retention time (min) & $\begin{array}{l}\text { Standard } \\
\text { deviation }\end{array}$ \\
\hline Benzene & 10.48 & 0.08 \\
Toluene & 13.92 & 0.02 \\
Ethylbenzene & 16.21 & 0.06 \\
Para-xylene and meta-xylene & 16.46 & 0.04 \\
Orto-xylene & 16.91 & 0.03 \\
Propylbenzene & 17.46 & 0.01 \\
trans-Decalin & 19.49 & 0.00 \\
cis-Decalin & 19.94 & 0.03 \\
Tetralin & 20.42 & 0.01 \\
Naphthalene & 20.59 & 0.05 \\
\hline
\end{tabular}

obtained after injecting five times a sample of each pure hydrocarbon and some mixtures (Table 2).

Figure 3 shows a typical chemical characterization of a liquid product.

The selectivity $\left(S_{i, j}\right.$, wt $\left.\%\right)$ of each $i$ hydrocarbon in the $j$ phase (gas and liquid) was calculated by the following equation:

$S_{i, j}=\frac{100 \times X_{i}}{\operatorname{Total}_{j}}$

where $X_{i}$ is the outlet mass concentration (wt $\%$ ) of each $i$ hydrocarbon identified in the gas or liquid product $(j)$. The overall balance of hydrocarbons was closed to $100 \%$ for each one of these fractions for comparison purposes.

The tetralin conversion (TC, wt\%) was calculated as follows:

$\mathrm{TC}=100-\frac{\left(F_{\mathrm{L}} \times S_{\mathrm{T}}\right)}{100}$

where $F_{\mathrm{L}}$ is the liquid fraction and $S_{\mathrm{T}}$ is the tetralin selectivity (Eq. 1).

The BTX selectivity $\left(S_{\mathrm{BTX}}\right)$ in the liquid phase was obtained by summing the selectivity values for benzene, toluene, ethylbenzene, and meta-, para- and orto-xylenes.

The BTX yield was obtained by multiplying the liquid fraction $\left(F_{\mathrm{L}}\right)$ by the BTX selectivity $\left(S_{\mathrm{BTX}}\right)$ divided by 100

$Y_{\mathrm{BTX}}=\frac{F_{\mathrm{L}} S_{\mathrm{BTX}}}{100}$
Fig. 3 Characterization of a typical HYC product with a 20/80 wt \% mixture of NiMo/ $\mathrm{Al}_{2} \mathrm{O}_{3} / / Z \mathrm{ZSM}-5$ under the following experimental conditions: $500{ }^{\circ} \mathrm{C}, 4.9 \mathrm{MPa}, \mathrm{H}_{2} /$ feed volume ratio of $267 \mathrm{~m}^{3} / \mathrm{m}^{3}$ and LHSV of $1.3 / \mathrm{h}$

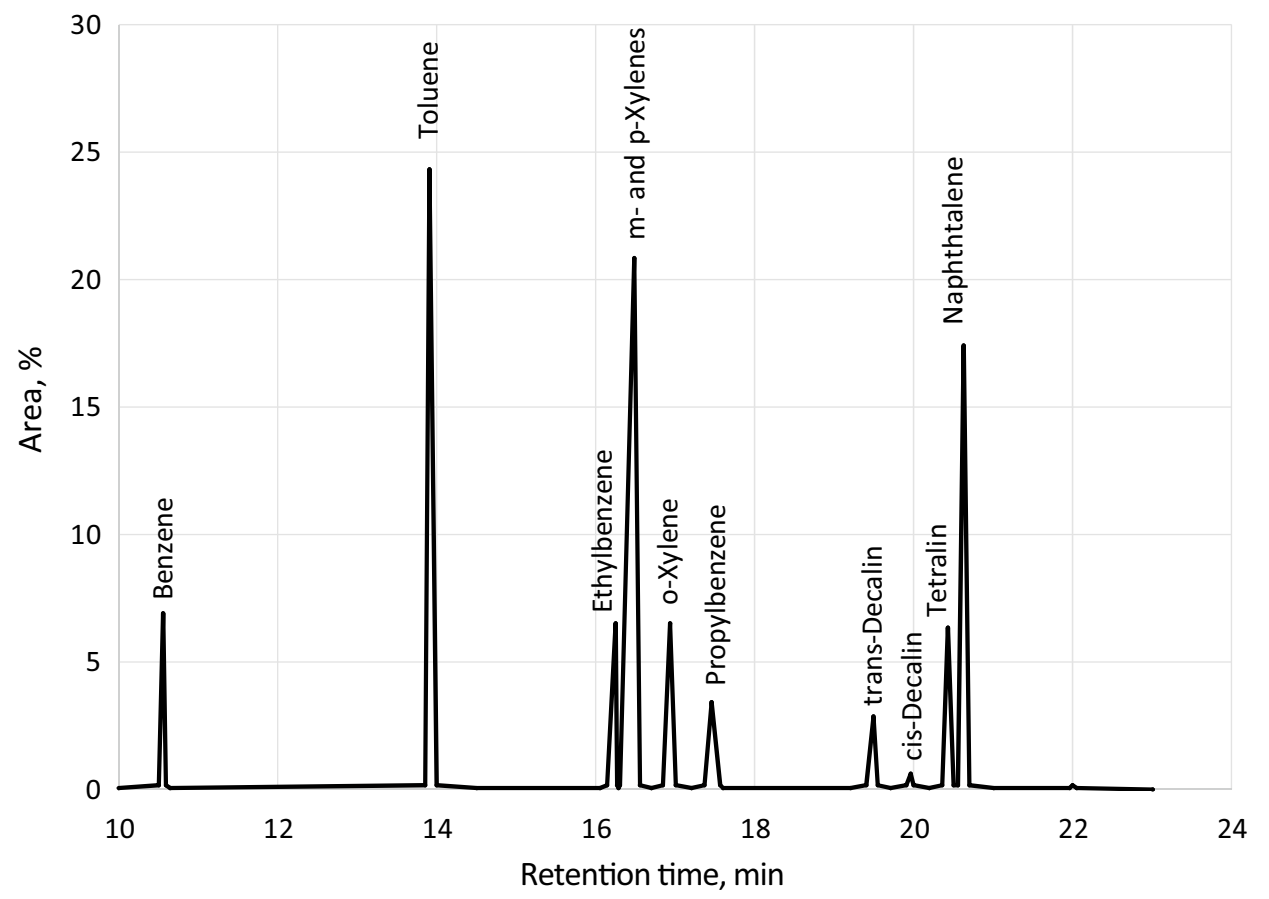




\section{Catalyst deactivation}

From the experiments at $500{ }^{\circ} \mathrm{C}, 4.9 \mathrm{MPa}, \mathrm{H}_{2}$ /feed volume ratio of $267 \mathrm{~m}^{3} / \mathrm{m}^{3}$ and LHSV of $1.3 / \mathrm{h}$ during the TOS of $144 \mathrm{~h}$, the activity $(A)$ of the catalyst was calculated using a non-linear equation fitting of the empirical Eq. (4) [12]. The mathematical fitting was carried out using the PolymathTM 6.1 software:

$\frac{\mathrm{TC}_{\mathrm{k}}}{100}=\frac{1}{\left(1+A t^{n}\right)}$

where $\mathrm{TC}_{\mathrm{k}}$ is the tetralin conversion at $k$ time (h), and $A$ and $n$ are fitting parameters which are functions of the feed.

The yields of coke precursors $\left(Y_{\mathrm{c}}\right)$ were calculated considering the weight of polymerized carbon $\left(W_{\mathrm{c}}\right.$, Sect. 2.1) and the total feed weight $\left(W_{\mathrm{f}}\right)$ after $144 \mathrm{~h}$ of TOS to facilitate comparisons:

$Y_{\mathrm{c}}=\frac{100 \times W_{\mathrm{c}}}{W_{\mathrm{f}}}$

\section{Results and discussion}

\section{Characterization of the ZSM-5 and NiMo/ $\mathrm{Al}_{2} \mathrm{O}_{3}$ catalysts}

The physical properties of the $\mathrm{NiMo} / \mathrm{Al}_{2} \mathrm{O}_{3}$ and ZSM-5 materials are shown in Table 1 . The maximum pore diameter of ZSM-5, according to the Database of zeolite structures [7], is $0.636 \mathrm{~nm}$. As expected, ZSM-5 presented higher values for Brönsted acid sites than $\mathrm{NiMo} / \mathrm{Al}_{2} \mathrm{O}_{3}$. This property is very important for hydrocracking purposes $[11,15,22$, 23]. However, the presence of the metallic function (NiMo) in adequate amounts is necessary for decreasing the catalytic deactivation $[15,19,20]$.

HRTEM studies were performed on the sulfided $\mathrm{NiMo} /$ $\mathrm{Al}_{2} \mathrm{O}_{3}$ catalyst after reaction in order to get information about the sulfide phase. As the micrograph shows (Fig. 4a), typical fringes due to NiMoS are exhibited, confirming that the oxide precursors were transformed during the sulfidation stage. The distribution of the staking degree and slab length are typical of this kind of supported metals catalyst (Fig. 4b). The length of the layers varied from 3.9 to $8.5 \mathrm{~nm}[5,11]$.

\section{Effect of the experimental conditions on the tetralin conversion and selectivity using a NiMo/ $/ \mathrm{Al}_{2} \mathrm{O}_{3}$ catalyst}

Table 3 shows the effect of the operating conditions on the selectivity to BTX and other compounds when using a $\mathrm{NiMo} / \mathrm{Al}_{2} \mathrm{O}_{3}$ catalyst. The temperature was kept at $500{ }^{\circ} \mathrm{C}$,

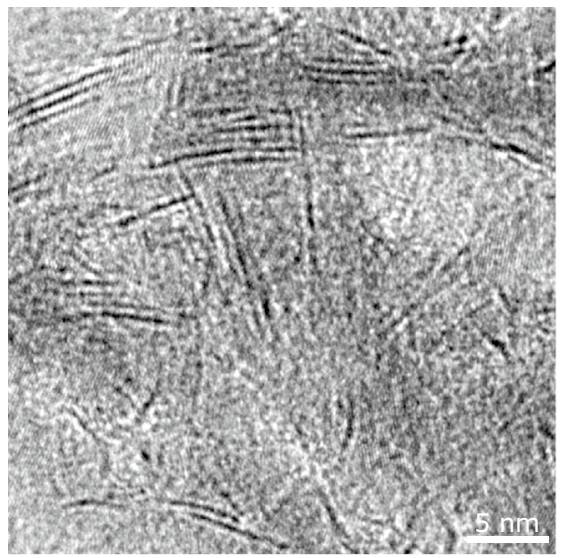

(a)

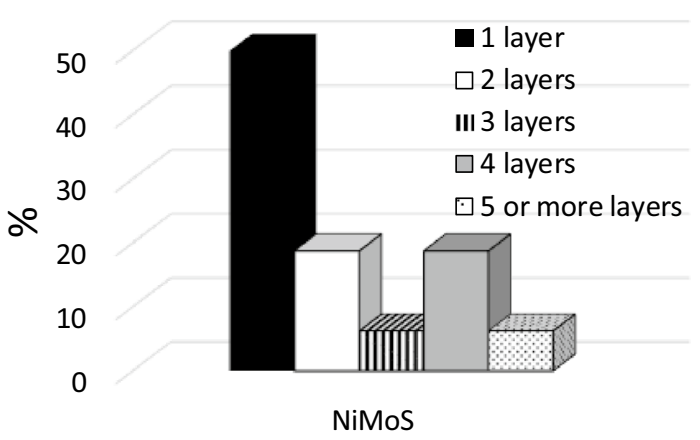

(b)

Fig. 4 a HRTEM micrograph of the sulfided $\mathrm{NiMo} / \mathrm{Al}_{2} \mathrm{O}_{3}$ commercial catalyst. b Distribution of staking degree and slab length for the same catalyst

which is required for BTX formation with this catalyst; below this temperature, no BTX was detected. The tetralin conversion was between 94 and $100 \mathrm{wt} \%$ under the evaluated experimental conditions. Gas and liquid fractions remained almost constant under all the studied experimental conditions with average values of 2 and $98 \mathrm{wt} \%$, respectively.

Regarding the selectivity of the products, in this case in the gas fraction, $\mathrm{C}_{2}-\mathrm{C}_{3}$ were the principal present hydrocarbons with selectivity between 22 and $41 \%$. In the case of the liquid composition, tetralin was mainly transformed into naphthalene (84.2-88.5 wt\%) with slight presence of BTX (6.7-9.5 wt\%) and decalins (1.5-3.0 wt\%). The BTX yield was never above $10 \mathrm{wt} \%$, being the high HYD/DEHYD value due mostly to the presence of naphthalene and just a small amount of decalin derivatives. The naphthalene presence may not be only caused by the thermodynamic equilibrium that favors the tetralin dehydrogenation reaction $[1,16]$, but also by the thermal cracking as a result of the extremely severe experimental conditions used $\left(450-500{ }^{\circ} \mathrm{C}\right.$, 3.9-4.9 $\mathrm{MPa}$ and $\mathrm{H}_{2} /$ feed volume ratio of $178-267 \mathrm{~m}^{3} / \mathrm{m}^{3}$ ) 
Table 3 Effect of the experimental conditions on the tetralin hydrocracking with $\mathrm{NiMo} / \mathrm{Al}_{2} \mathrm{O}_{3}$

\begin{tabular}{|c|c|c|c|c|c|c|}
\hline Temperature $\left({ }^{\circ} \mathrm{C}\right)$ & 500 & 500 & 500 & 500 & 500 & 500 \\
\hline Pressure (MPa) & 3.9 & 4.9 & 5.9 & 3.9 & 4.9 & 5.9 \\
\hline $\operatorname{LHSV}(/ \mathrm{h})$ & 1.30 & 1.30 & 1.30 & 1.30 & 1.30 & 1.30 \\
\hline $\mathrm{H}_{2} /$ feed $\left(\mathrm{m}^{3} / \mathrm{m}^{3}\right)$ & 177.51 & 177.51 & 177.51 & 267.47 & 267.47 & 267.47 \\
\hline Tetralin conversion (wt $\%$ ) & 100.00 & 95.64 & 94.70 & 99.92 & 99.96 & 94.32 \\
\hline Liquid fraction (wt $\%$ ) & 97.83 & 98.06 & 98.17 & 98.38 & 97.74 & 97.65 \\
\hline Gas fraction (wt $\%$ ) & 2.17 & 1.94 & 1.83 & 1.62 & 2.26 & 2.35 \\
\hline \multicolumn{7}{|c|}{ Gas product distribution (HC) (wt\%) } \\
\hline $\mathrm{C}_{1}$ & 9.92 & 9.73 & 11.21 & 6.79 & 7.24 & 4.45 \\
\hline $\mathrm{C}_{2}$ & 30.87 & 31.67 & 33.60 & 26.53 & 28.12 & 22.13 \\
\hline $\mathrm{C}_{3}$ & 36.25 & 36.66 & 36.90 & 37.71 & 38.70 & 40.52 \\
\hline $\mathrm{C}_{4}$ & 18.02 & 16.92 & 14.68 & 22.38 & 20.17 & 24.90 \\
\hline $\mathrm{C}_{5+}$ & 4.94 & 5.02 & 3.60 & 6.59 & 5.77 & 7.99 \\
\hline Subtotal & 100.00 & 100.00 & 100.00 & 100.00 & 100.00 & 100.00 \\
\hline \multicolumn{7}{|l|}{ Liquid product distribution (wt\%) } \\
\hline Benzene & 0.16 & 0.28 & 0.47 & 0.36 & 0.47 & 0.36 \\
\hline Toluene & 1.39 & 1.88 & 2.02 & 1.75 & 1.91 & 1.23 \\
\hline Ethylbenzene & 1.72 & 1.56 & 1.67 & 1.56 & 1.82 & 1.23 \\
\hline Meta- and para-xylenes & 4.40 & 3.45 & 3.12 & 4.52 & 4.35 & 2.72 \\
\hline Orto-xylene & 0.79 & 1.18 & 1.32 & 1.66 & 1.63 & 1.60 \\
\hline trans-Decalin & 2.79 & 1.65 & 1.38 & 2.38 & 2.34 & 1.56 \\
\hline cis-Decalin & 0.23 & 0.17 & 0.12 & 0.15 & 0.31 & 0.11 \\
\hline Tetralin & 0.00 & 4.62 & 5.65 & 0.08 & 0.05 & 6.00 \\
\hline Naphthalene & 88.52 & 85.21 & 84.25 & 87.55 & 87.11 & 85.21 \\
\hline Subtotal & 100.00 & 100.00 & 100.00 & 100.00 & 100.00 & 100.00 \\
\hline BTX selectivity (wt\%) & 8.46 & 8.35 & 8.6 & 9.85 & 10.18 & 7.14 \\
\hline HYD/DEHYD selectivity (wt\%) & 91.55 & 87.03 & 85.75 & 90.08 & 89.76 & 86.88 \\
\hline BTX yield (wt\%) & 8.28 & 8.19 & 8.43 & 9.66 & 9.98 & 8.19 \\
\hline HYD/DEHYD yield (wt\%) & 89.57 & 85.34 & 84.09 & 88.33 & 88.02 & 85.34 \\
\hline
\end{tabular}

$[4,23]$. It is worth remembering that although the aromatic hydrogenation is reversible, exothermic, and thermodynamically favorable at $200-250{ }^{\circ} \mathrm{C}$ and $3-5 \mathrm{MPa}$ with hydrogenation equilibrium constants below the unit at $350{ }^{\circ} \mathrm{C}$ [1] according to Boucenaur et al. [4] at $500{ }^{\circ} \mathrm{C}$, only 8 min on stream were required for $30 \%$ of tetralin conversion and as the temperature increased, the naphthalene presence linearly increased above other thermal cracked products like 1-methylindane and $n$-butylbenzene. Therefore, the result indicates that naphthalene can be formed either by the thermodynamic equilibrium $[1,16]$ and/or as a thermal cracking by-product [4]. The low observed BTX amount was the result of the lack of strong acidic functions in the catalyst $[11,18]$.

\section{Effect of the experimental conditions on tetralin conversion and selectivity using ZSM-5}

Table 4 shows the impact of the experimental conditions on the tetralin conversion when ZSM-5 was used as catalyst. As the temperature increased from 450 to $500{ }^{\circ} \mathrm{C}$, the tetralin conversions increased sharply from 18 to $93 \mathrm{wt} \%$ at
3.9 $\mathrm{MPa}$, and from 20 to almost $100 \mathrm{wt} \%$ at 4.9 MPa. The liquid and gas fractions were also affected by temperature and pressure. The liquid fraction decreased strongly (from 98.4 to 71.8 and from 99.1 to $69.7 \mathrm{wt} \%)$ at gas (1.6-28.2 and from 0.9 to $30.3 \mathrm{wt} \%$ ) formation expenses. It is evident that the acidic nature, pore size and topology of ZSM-5 promoted the hydrocracking reaction, allowing the tetralin diffusion, ring opening and dealkylation reactions when all the strong acid sites were reached. Nevertheless, the slower aromatic diffusion due to zeolite pore size could also have promoted the deactivation reaction $[12,13]$ increasing the dehydrogenation and shortening the cycle length.

Regarding the selectivity of the gas phase, it showed that at $450{ }^{\circ} \mathrm{C}$, the formation of $\mathrm{C}_{3}$ and $\mathrm{C}_{4}$ hydrocarbons was favored while at $500{ }^{\circ} \mathrm{C}$, the main products were $\mathrm{C}_{3}$.

About the selectivity in the liquid phase, the BTX selectivity was increased notably at $500{ }^{\circ} \mathrm{C}(68.8$ and $84.2 \mathrm{wt} \%)$ compared to the experiment at $450{ }^{\circ} \mathrm{C}(4.1$ and $3.5 \mathrm{wt} \%)$ at 3.9 and 4.9 $\mathrm{MPa}$. However, naphthalene was also observed at both 450 and $500{ }^{\circ} \mathrm{C}$. As it was noted, the naphthalene formation may be due to either tetralin/naphthalene 
Table 4 Effect of the experimental conditions on the tetralin hydrocracking with ZSM-5

\begin{tabular}{lllll}
\hline Temperature $\left({ }^{\circ} \mathrm{C}\right)$ & 450 & 500 & 450 & 500 \\
Pressure (MPa) & 3.9 & 3.9 & 4.9 & 4.9 \\
LHSV (/h) & 1.30 & 1.30 & 1.30 & 1.30 \\
$\mathrm{H}_{2} /$ feed $\left(\mathrm{m}^{3} / \mathrm{m}^{3}\right.$ ) & 267.47 & 267.47 & 267.47 & 267.47 \\
Tetralin conversion (wt\%) & 17.69 & 93.19 & 20.14 & 99.73 \\
Liquid fraction (wt\%) & 98.36 & 71.77 & 99.07 & 69.73 \\
Gas fraction (wt\%) & 1.64 & 28.23 & 0.93 & 30.27 \\
Gas product distribution (HC) $(\mathrm{wt} \%)$ & & & \\
$\mathrm{C}_{1}$ & 2.25 & 9.98 & 5.54 & 9.81 \\
$\mathrm{C}_{2}$ & 7.35 & 16.32 & 11.17 & 20.42 \\
$\mathrm{C}_{3}$ & 53.43 & 56.80 & 51.11 & 55.19 \\
$\mathrm{C}_{4}$ & 32.83 & 16.38 & 27.76 & 14.07 \\
$\mathrm{C}_{5+}$ & 4.15 & 0.52 & 4.42 & 0.52 \\
Subtotal & 100.00 & 100.00 & 100.00 & 100.00 \\
Liquid product distribution (wt\%) & & & & \\
Benzene & 0.67 & 3.50 & 0.73 & 8.26 \\
Toluene & 0.29 & 24.08 & 0.20 & 29.94 \\
Ethylbenzene & 1.80 & 6.40 & 0.97 & 5.56 \\
Meta- and para-xylenes & 0.57 & 26.76 & 0.71 & 30.37 \\
Orto-xylene & 0.73 & 8.04 & 0.90 & 10.10 \\
trans-Decalin & 0.20 & 0.29 & 0.00 & 1.22 \\
cis-Decalin & 0.00 & 0.00 & 0.00 & 0.01 \\
Tetralin & 85.31 & 10.72 & 84.73 & 0.46 \\
Naphthalene & 10.44 & 20.20 & 11.76 & 14.08 \\
Subtotal & 100.00 & 100.00 & 100.00 & 100.00 \\
BTX selectivity (wt\%) & 4.05 & 68.78 & 3.51 & 84.23 \\
HYD/DEHYD selectivity (wt\%) & 10.64 & 20.50 & 11.76 & 15.31 \\
BTX yield (wt\%) & 3.98 & 49.36 & 3.48 & 58.73 \\
HYD/DEHYD yield (wt\%) & 10.47 & 14.71 & 11.65 & 10.67 \\
\hline & & & & \\
& & & & \\
& & & &
\end{tabular}

thermodynamic equilibrium $[1,16]$ and/or thermal cracking processes $[4,22]$. It is quite important to remember that ZSM-5 is a zeolite with relatively small pore size and it has been found that the size of the pores may vary the product distribution. That is, a larger cage allows the reaction to proceed to a wider array of products [20, 22, 23]. It is noteworthy that benzene, meta- and para-xylene must be formed by transalkylation reactions [23, 24] from ortoxylene, ethyl-benzene, and toluene, which can be obtained by direct hydrocracking of tetralin by releasing ethane and propane. Additionally, the presence of the aromatic compounds, including BTX, can be the result of bimolecular processes involving hydrogen transfer reactions catalyzed by ZSM-5, as Townsend and Abbot [23] have suggested. The selectivity to BTX was close to $85 \mathrm{wt} \%$ when the pressure was raised from 3.9 to $4.9 \mathrm{MPa}$. Nevertheless, by combining the BTX selectivity with the amount of liquid fraction, the BTX yield reached up to $59 \mathrm{wt} \%$ at $500{ }^{\circ} \mathrm{C}$ and $4.9 \mathrm{MPa}$.

\section{Effect of the experimental conditions on the tetralin conversion and selectivity on the $\mathrm{NiMo} / \mathrm{Al}_{2} \mathrm{O}_{3} / /$ ZSM-5 mixtures}

Figures 5, 6, 7 and 8 show the effect of the testing conditions on the tetralin conversion using $\mathrm{NiMo} / \mathrm{Al}_{2} \mathrm{O}_{3}, \mathrm{ZSM}-5$ and NiMo/ $/ \mathrm{Al}_{2} \mathrm{O}_{3} / / \mathrm{ZSM}-5$ mixtures. In Fig. 5, through the hydrocracking reaction, as the ZSM-5 content was increased in the $\mathrm{NiMo} / \mathrm{Al}_{2} \mathrm{O}_{3} / / \mathrm{ZSM}-5$ mixture, the tetralin conversion varied, being the lowest for the $50 / 50 \mathrm{NiMo} / \mathrm{Al}_{2} \mathrm{O}_{3} / /$ ZSM-5 mixture ( $86 \mathrm{wt} \%$ ). The liquid fraction fell from 98.4 to $69.7 \mathrm{wt} \%$ as the ZSM-5 content was increased, and the gas formation increased (from 1.6 to $30.3 \mathrm{wt} \%$ ). Obviously, as the zeolite amount was increased, the hydrocracking process was favored, giving place to hydrocracking products such as mono-aromatics and gases. This result may be due to the pore size of the ZSM-5 zeolite used as co-catalyst in this work [16].

In the case of the hydrocarbon distribution in the gas phase (Fig. 6), $\mathrm{C}_{3}$ was the major product. The effect of increasing the $\mathrm{ZSM}-5$ content in the $\mathrm{NiMo} / \mathrm{Al}_{2} \mathrm{O}_{3} / / \mathrm{ZSM}-5$ mixture reduced the $\mathrm{C}_{3}$ amount and increased the $\mathrm{C}_{1}$ and $\mathrm{C}_{2}$ presence. Lee et al. [16] found out that $\mathrm{C}_{3}$ and $\mathrm{C}_{4}$ were the main components when the metals were supported on H-beta zeolite.

As for the liquid fraction (Fig. 7), as the amount of the ZSM- 5 content was increased in the $\mathrm{NiMo} / \mathrm{Al}_{2} \mathrm{O}_{3} / / \mathrm{ZSM}-5$ mixture, the naphthalene presence began to decrease, yielding hydrocracked products: benzene, toluene, ethylbenzene, meta-, para- and orto-xylene. The main products obtained with the $50 / 50 \mathrm{NiMo} / \mathrm{Al}_{2} \mathrm{O}_{3} / / \mathrm{ZSM}-5$ mixtures were naphthalene, followed by ethylbenzene, toluene and meta- and paraxylene. As it was already said, naphthalene can be the result of the thermodynamic equilibrium [1] and thermal cracking [4] of tetralin while the hydrocracked products depended on the more active presence of the ZSM-5 acid sites. Ethylbenzene, toluene and orto-xylene can be obtained by direct hydrocracking while benzene, meta- and para-xylene by disproportionation and trans-alkylation processes [23, 24]. As the amount of ZSM-5 was increased, naphthalene and ethylbenzene began to decrease and toluene and xylenes increased. The presence of relatively small aromatic compounds can be related to the small zeolite pores, which favor the formation of less voluminous hydrocarbon molecules as some experiments have shown [16, 22, 23].

The most important products found by Lee et al. [16] when using $\mathrm{Ni}, \mathrm{Ni}-\mathrm{Sn}, \mathrm{CoMo}-\mathrm{S}$ on $\mathrm{H}-\mathrm{Beta}$ zeolite during the tetralin hydrocracking were benzene and toluene, followed by ethylbenzene and xylenes under almost all the experimental conditions. They also reported the presence of $\mathrm{C}_{9}$ to $\mathrm{C}_{11}$ aromatic compounds, indane and methylindane, naphthalene, and 1- and 2-methylnaphthalenes at very low 
Fig. 5 Effect of the presence of ZSM-5 in the $\mathrm{NiMo} / \mathrm{Al}_{2} \mathrm{O}_{3} / /$ ZSM-5 mixtures on the tetralin conversion, liquid, and gas fractions under the following experimental conditions: $500{ }^{\circ} \mathrm{C}, 4.9 \mathrm{MPa}, \mathrm{H}_{2} /$ feed volume ratio of $267 \mathrm{~m}^{3} / \mathrm{m}^{3}$, and LHSV of $1.3 / \mathrm{h}$

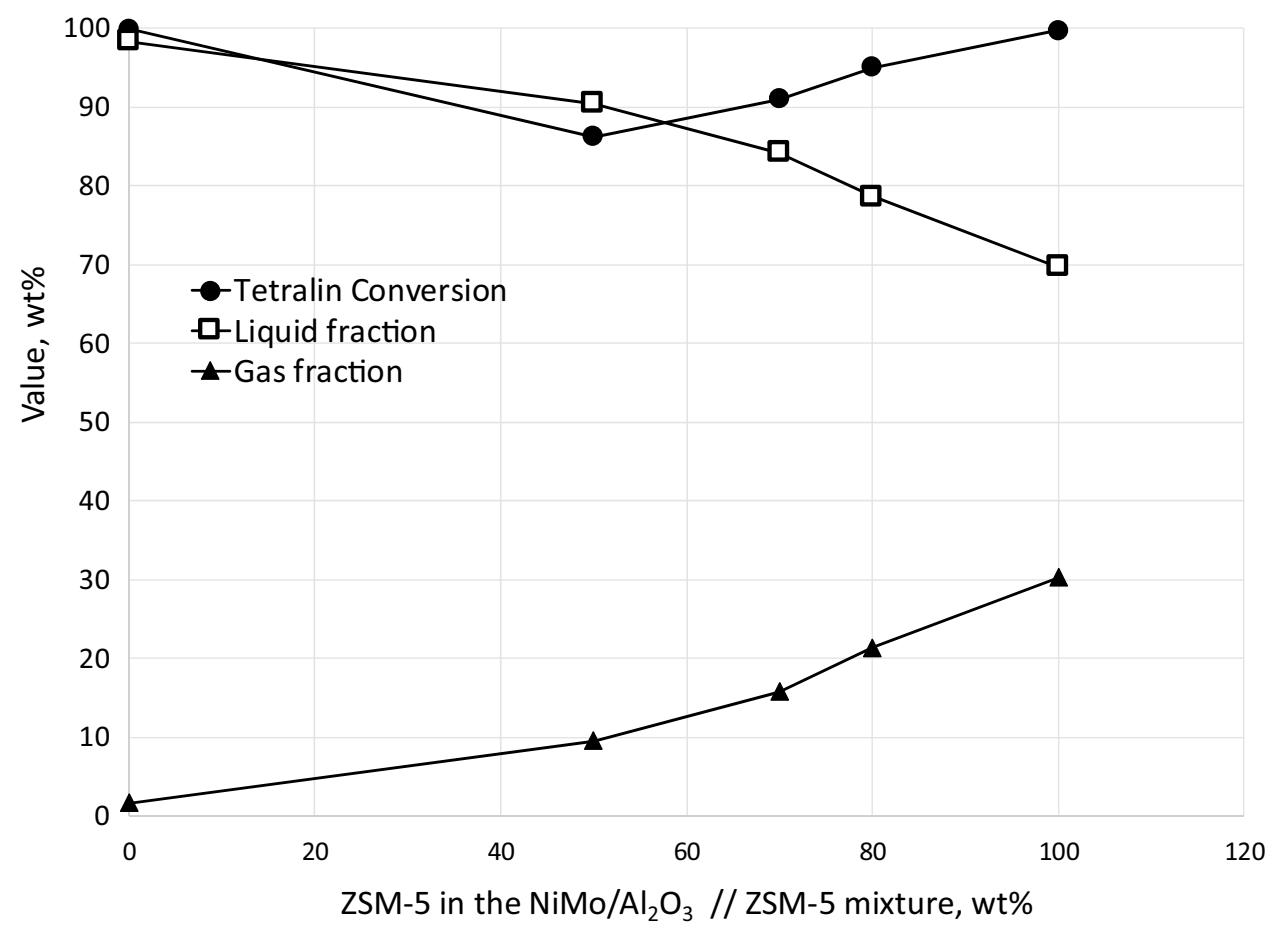

Fig. 6 Effect of the presence of ZSM-5 in the NiMo/ $\mathrm{Al}_{2} \mathrm{O}_{3} / / Z \mathrm{ZSM}-5$ mixtures on the hydrocarbons distribution in the gas fraction under the following experimental conditions: $500{ }^{\circ} \mathrm{C}, 4.9 \mathrm{MPa}, \mathrm{H}_{2} /$ feed volume ratio of $267 \mathrm{~m}^{3} / \mathrm{m}^{3}$, and LHSV of $1.3 / \mathrm{h}$

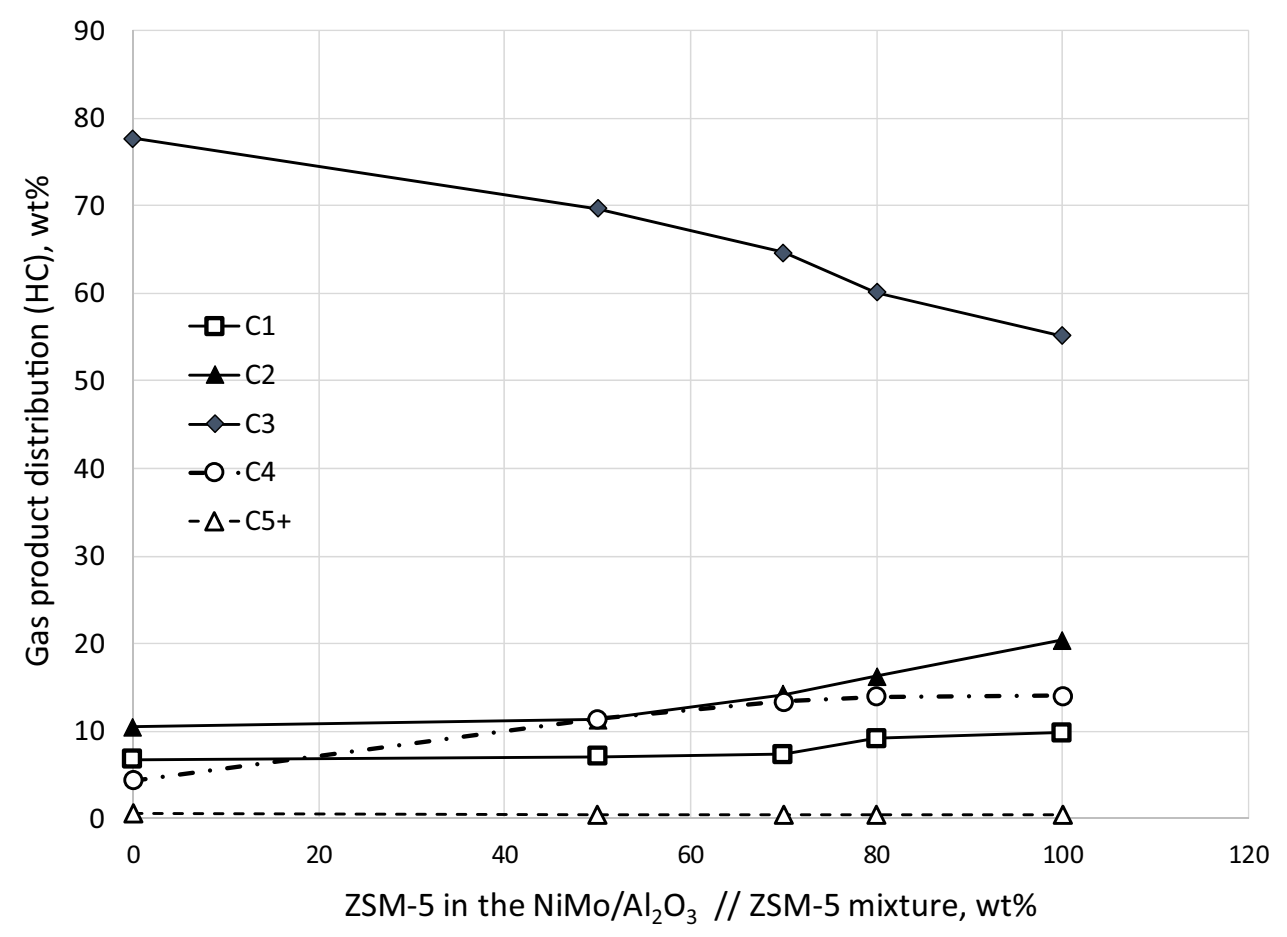

concentrations. It is rather interesting to observe in their work that the presence of naphthalene was very low considering that the conversion of tetralin was above $79 \mathrm{wt} \%$. The reason behind the lack of $\mathrm{C}_{9+}$ aromatic compounds in our experiments can be explained by the zeolite type. According to the Database of zeolite structures, H-Beta zeolite with a pore diameter of $0.67-0.69 \mathrm{~nm}$ instead of ZSM-5 $(0.55-0.56 \mathrm{~nm})$ [7] may produce a wider array of products $[16,22,23]$. Additionally, it has been reported that zeolite ZSM-5 favors the formation of BTX hydrocarbons [16, 20].

In Fig. 8, the effect of the ZSM-5 content on the BTX selectivity and yield can be seen. The BTX selectivity 
Fig. 7 Effect of the presence of ZSM-5 in the NiMo/ $\mathrm{Al}_{2} \mathrm{O}_{3} / / \mathrm{ZSM}-5$ mixtures on the hydrocarbons distribution in the liquid fraction under the following experimental conditions: $500{ }^{\circ} \mathrm{C}, 4.9 \mathrm{MPa}, \mathrm{H}_{2} /$ feed volume ratio of $267 \mathrm{~m}^{3} / \mathrm{m}^{3}$, and LHSV of $1.3 / \mathrm{h}$
Fig. 8 Effect of the presence of ZSM-5 in the $\mathrm{NiMo} / \mathrm{Al}_{2} \mathrm{O}_{3} / /$ ZSM-5 mixtures on the BTX selectivity and BTX yield under the following experimental conditions: $500{ }^{\circ} \mathrm{C}, 4.9 \mathrm{MPa}$, $\mathrm{H}_{2} /$ feed volume ratio of $267 \mathrm{~m}^{3} /$ $\mathrm{m}^{3}$, and LHSV of $1.3 / \mathrm{h}$
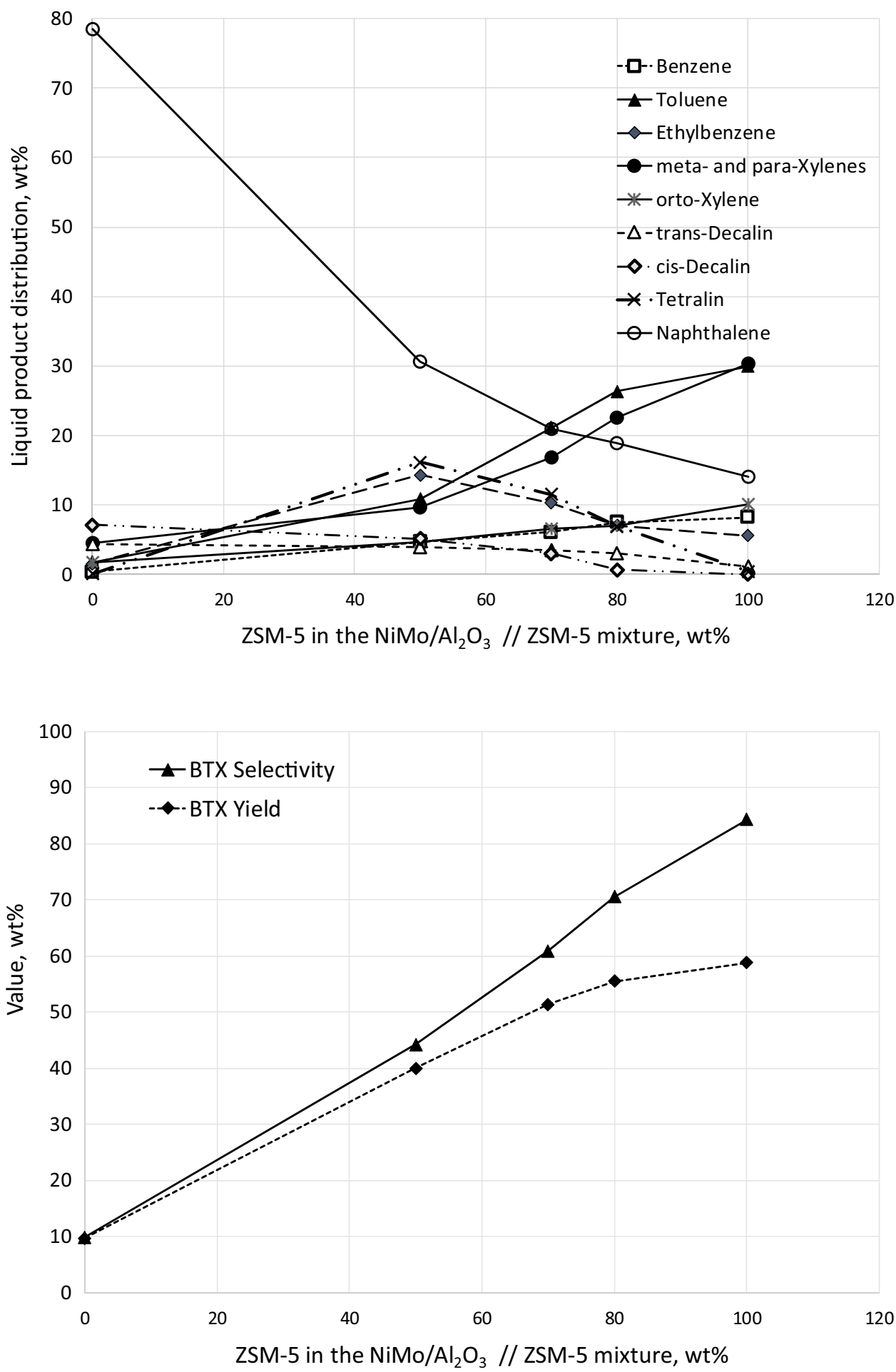

increased from 9.1 to 84.2 as the ZSM-5 amount was increased. However, the BTX yield reached a plateau at $55-58 \mathrm{wt} \%$ for the $20 / 80 \mathrm{NiMo} / \mathrm{Al}_{2} \mathrm{O}_{3} / / Z \mathrm{ZSM}-5$ mixture and ZSM-5, which resulted from the decrement in the liquid fraction.

\section{Effect of the acidic properties of the catalysts versus $B T X$ yield}

Table 1 includes the Brönsted and Lewis acidity of the $\mathrm{NiMo} / \mathrm{Al}_{2} \mathrm{O}_{3}$ catalyst and ZSM-5. As expected, the acidity decreased when the temperature increased up to $400{ }^{\circ} \mathrm{C}$ for both catalysts. The Brönsted acidity was clearly lower than 
Fig. 9 Relationship between the Brönsted acidity and the BTX selectivity at $500{ }^{\circ} \mathrm{C}, 4.9 \mathrm{MPa}$, 1.3/h LHSV and $\mathrm{H}_{2} /$ feed volume ratio of $267 \mathrm{~m}^{3} / \mathrm{m}^{3}$

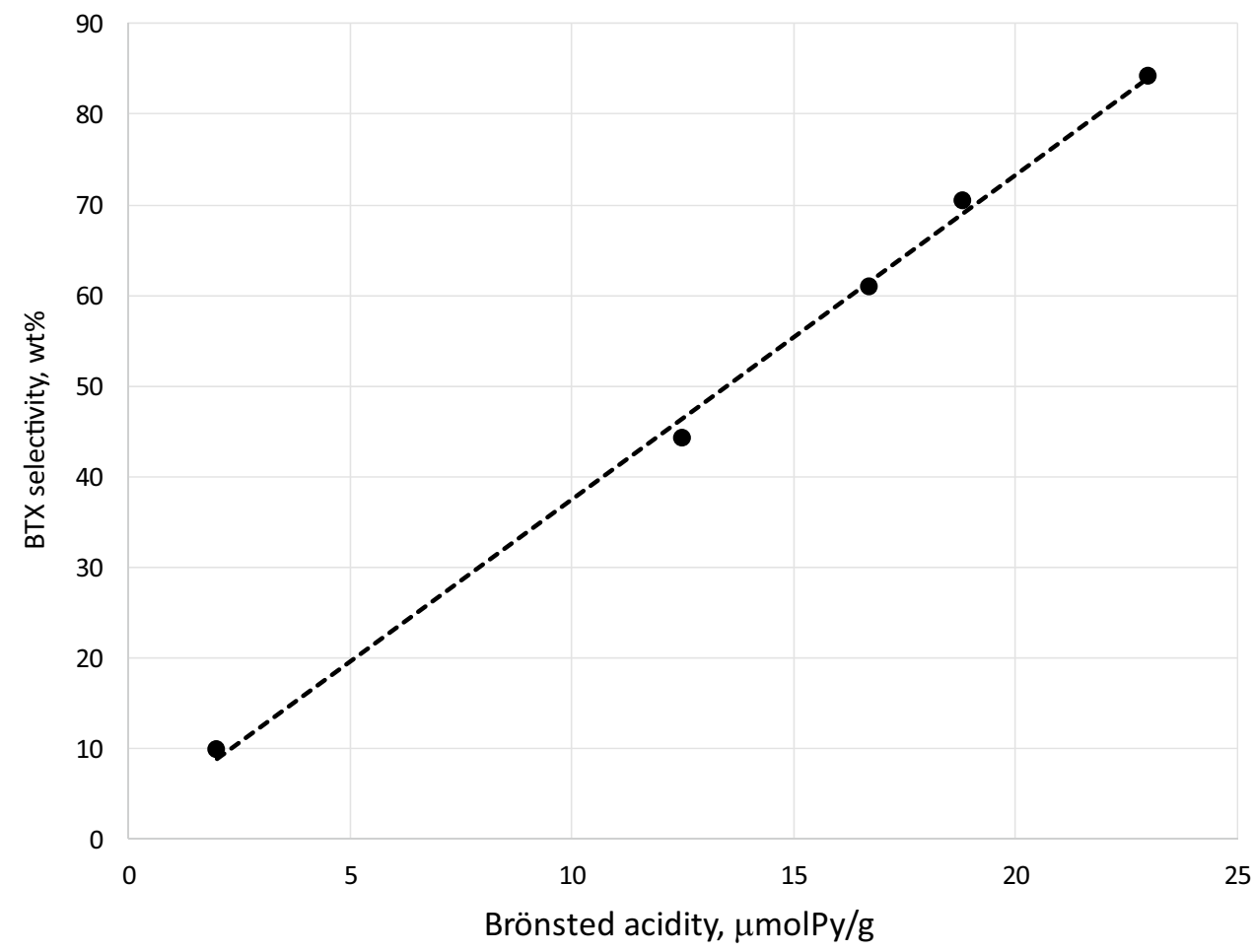

the Lewis acidity in the $\mathrm{NiMo} / \mathrm{Al}_{2} \mathrm{O}_{3}$ catalyst and at $400{ }^{\circ} \mathrm{C}$ in ZSM-5. The Brönsted acidity in the $\mathrm{NiMo} / \mathrm{Al}_{2} \mathrm{O}_{3}$ catalyst was lower than in ZSM-5; on the other hand, the Lewis and total acidity in the $\mathrm{NiMo} / \mathrm{Al}_{2} \mathrm{O}_{3}$ catalyst were higher than in ZSM-5. Finally, the Brönsted acidity of the catalyst/zeolite mixture at $400{ }^{\circ} \mathrm{C}$ can be more important than the Lewis acidity for the BTX formation. Figure 9 shows a relationship between the Brönsted acidity of the NiMo/zeolite mixture at $400{ }^{\circ} \mathrm{C}$ and the selectivity to BTX considering only the liquid products at $500{ }^{\circ} \mathrm{C}, 4.9 \mathrm{MPa}, 1.3 / \mathrm{h}$ and $\mathrm{H}_{2}$ /feed volume ratio of $267 \mathrm{~m}^{3} / \mathrm{m}^{3}$. To conclude, accessible, well-dispersed and strong Brönsted acid sites are highly recommended for the hydrocracking of tetralin into BTX [19].

\section{Deactivation rate of the tetralin hydroconversion by using $\mathrm{NiMo} / \mathrm{Al}_{2} \mathrm{O}_{3}, \mathrm{ZSM}-5$ and NiMo/Al${ }_{2} \mathrm{O}_{3} / / \mathrm{ZSM}-5$ mixtures}

The mechanism of coke deactivation on a catalyst is both chemical and physical; being the most important, the strong adsorption of polymerized carbon molecules on the acid sites. As polymerized carbon accumulates, the catalyst pores can be partially or totally blocked. Strong acid sites induce the formation of coke precursors, which undergo condensation reactions that produce large polynuclear aromatic molecules that can cover physically the catalytic surface $[2,13]$.

Metal moieties like those in the $\mathrm{NiMo} / \mathrm{Al}_{2} \mathrm{O}_{3}$ catalyst promoted the hydrogenation of polymerized carbon, minimizing

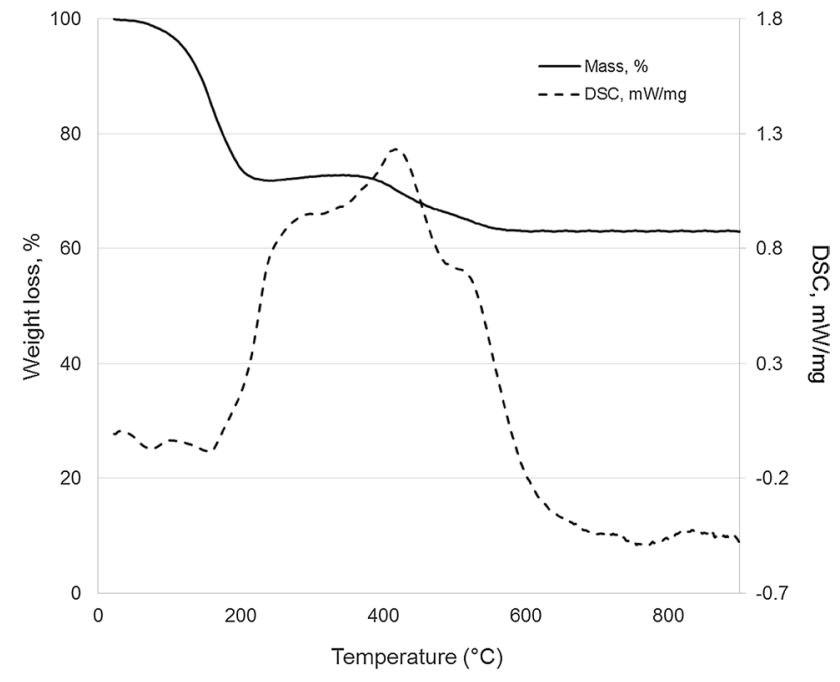

Fig. 10 DTA/DSC curve of the used $\mathrm{NiMo} / \mathrm{Al}_{2} \mathrm{O}_{3}$ catalyst in nitrogen atmosphere after the experiment at $500{ }^{\circ} \mathrm{C}, 4.9 \mathrm{MPa}, \mathrm{MPa}, \mathrm{H}_{2} / \mathrm{feed}$ volume ratio of $267 \mathrm{~m}^{3} / \mathrm{m}^{3}$, and LHSV of $1.3 / \mathrm{h}$

the deactivation and increasing the cycle length $[15,20]$. To minimize this deactivation, it is convenient to operate with an $\mathrm{H}_{2} /$ feed volume ratio of $267 \mathrm{~m}^{3} / \mathrm{m}^{3}$ or higher to maintain the selectivity to BTX otherwise low hydrogen partial pressures may promote more coke deposition [12].

Figure 10 shows the TGA mass loss curve for the NiMo/ $\mathrm{Al}_{2} \mathrm{O}_{3}$ catalyst recovered after the experiment under the following conditions: $500{ }^{\circ} \mathrm{C}, 4.9 \mathrm{MPa}, \mathrm{H}_{2} /$ feed volume ratio of $267 \mathrm{~m}^{3} / \mathrm{m}^{3}$, and LHSV of 1.3/h. Superimposed are 
the DSC results, which show the temperature difference. The decomposition began at $50{ }^{\circ} \mathrm{C}$ and ended at $600{ }^{\circ} \mathrm{C}$. After $600{ }^{\circ} \mathrm{C}$, no significant changes were observed. From 100 to $200^{\circ} \mathrm{C}$, an endothermic event was observed, which corresponded to the desorption of water and hydrocarbons physisorbed in the catalyst during the reaction. In the 200-600 ${ }^{\circ} \mathrm{C}$ interval, an exothermic event was detected, which corresponded to the combustion of organic agents in the catalyst $\left(W_{\mathrm{c}}\right)$. The total weight loss was $37 \mathrm{wt} \%$. The temperature interval that allowed the combustion of the organic material showed that no refractory coke was formed, but coke precursors that covered the acid sites of the catalyst support [17]. The observed mass loss versus temperature pattern (TGA) was very similar to the behavior observed by Upare et al. [25] when analyzing Mo/Beta and $\mathrm{CoMo} / \mathrm{Beta}$ catalysts, and it was attributed to water $\left(<200{ }^{\circ} \mathrm{C}\right)$ and coke or related hydrocarbons $\left(>350{ }^{\circ} \mathrm{C}\right)$.

The mass loss TGA curves for the ZSM- 5 material and $\mathrm{NiMo} / \mathrm{Al}_{2} \mathrm{O}_{3} / / \mathrm{ZSM}-5$ mixtures were very similar to the one observed for the NiMo catalyst (Fig. 10) after being used under the same experimental conditions $\left(500{ }^{\circ} \mathrm{C}\right.$, 4.9 $\mathrm{MPa}, \mathrm{H}_{2} /$ feed volume ratio of $267 \mathrm{~m}^{3} / \mathrm{m}^{3}$, and LHSV of $1.3 / \mathrm{h}$ ). Percentages of polymerized carbon (coke precursors) yields for all the experiments are shown in Table 5.

Figure 11 shows the tetralin conversion versus the TOS when the process of each catalyst or mixture was used in the deactivation experiment at $500{ }^{\circ} \mathrm{C}, 4.9 \mathrm{MPa}, \mathrm{H}_{2} /$ feed volume ratio of $267 \mathrm{~m}^{3} / \mathrm{m}^{3}$, and LHSV of $1.3 / \mathrm{h}$. Using these values, the activity rates were calculated (Table 5). In the same table, relative deactivation rates obtained by dividing the $\mathrm{NiMo} / \mathrm{Al}_{2} \mathrm{O}_{3}$ activity rate by the value obtained with ZSM-5 and the NiMo/ $\mathrm{Al}_{2} \mathrm{O}_{3} / / \mathrm{ZSM}-5$ mixtures are shown.

The activity rate $(A)$ of the $\mathrm{NiMo} / \mathrm{Al}_{2} \mathrm{O}_{3}$ catalyst was about $5.5 \times 10^{-5}$ due to its hydrogenation functions that helped to reduce the deactivation rate [12] ZSM-5 presented an activity rate $(A)$ of $1.22 \times 10^{-6} / \mathrm{h}$. This material displayed a relative deactivation rate that was 45 times faster than the
Table 5 Yield of coke precursors and calculated activity rates for the catalysts tested in this work for $144 \mathrm{~h}$ TOS under the following experimental conditions: $500{ }^{\circ} \mathrm{C}, 4.9 \mathrm{MPa}, 1.3 / \mathrm{h}, \mathrm{H}_{2} /$ feed volume ratio of $267 \mathrm{~m}^{3} / \mathrm{m}^{3}$

\begin{tabular}{llllll}
\hline $\mathrm{NiMo} / \mathrm{Al}_{2} \mathrm{O}_{3}$ & 100 & 50 & 30 & 20 & 0 \\
$\mathrm{ZSM}-5$ & 0 & 50 & 70 & 80 & 100 \\
Coke precursors $(w t \%)$ & 5.78 & 6.05 & 7.50 & 8.03 & 11.26 \\
Activity rate $(/ \mathrm{h})$ & $5.50 \mathrm{E}-05$ & $1.02 \mathrm{E}-05$ & $6.04 \mathrm{E}-06$ & $3.49 \mathrm{E}-06$ & $1.22 \mathrm{E}-06$ \\
Corr. coeff. & 0.9936 & 0.9752 & 0.9423 & 0.9305 & 0.9182 \\
Relative deactivation rate & 1.00 & 5.39 & 9.11 & 15.75 & 45.14 \\
$\left(A_{\mathrm{NiMo}} / A_{i}\right)$ & & & & & \\
\hline
\end{tabular}

The optimized $n$ value for comparison purposes was 2.28

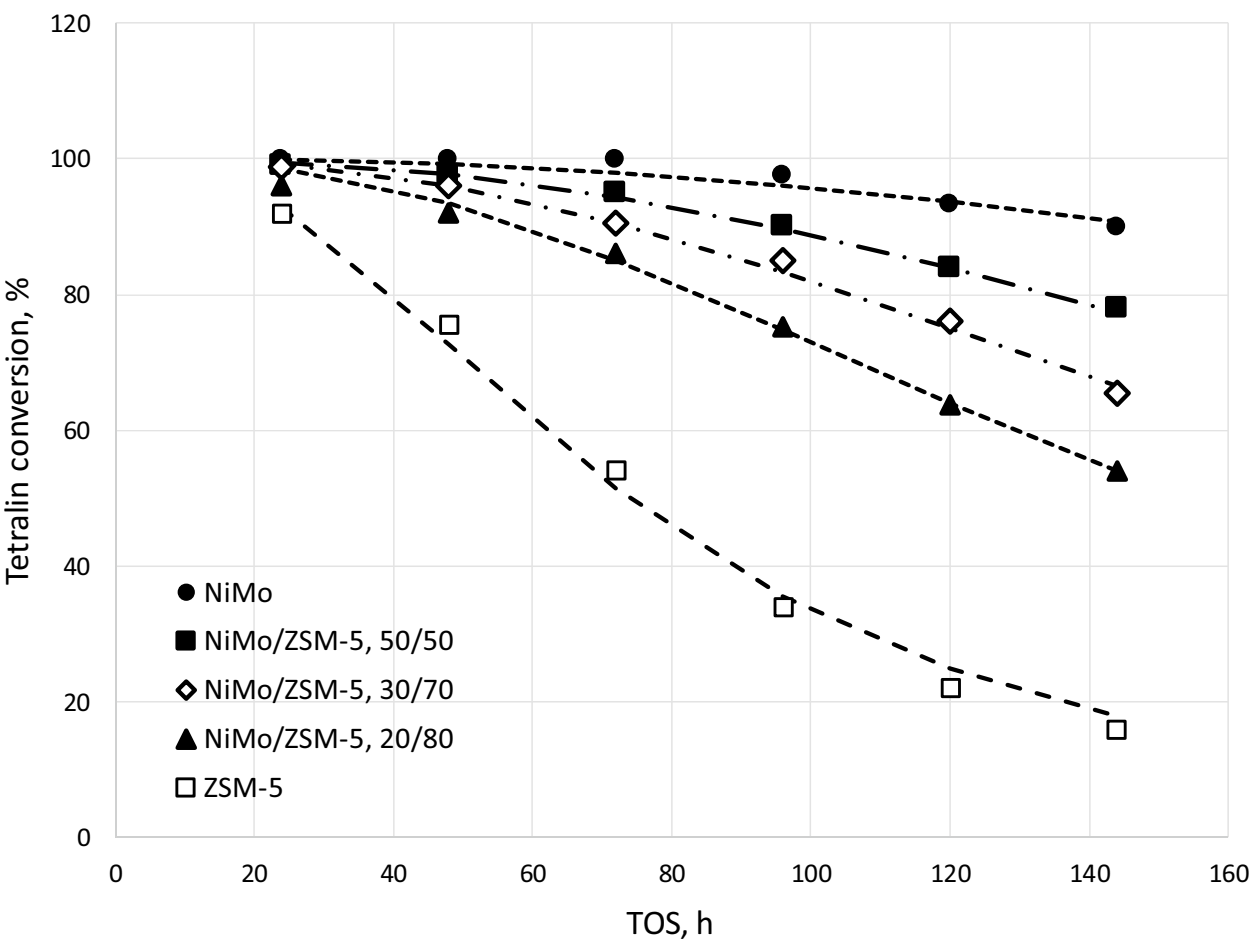

Fig. 11 Effect of the time on the tetralin conversion for the $\mathrm{NiMo} / \mathrm{Al}_{2} / \mathrm{O}_{3}, \mathrm{ZSM}-5$ and the $50 / 50,30 / 70$ and 20/80 NiMo/ $\mathrm{Al}_{2} \mathrm{O}_{3} / / \mathrm{ZSM}-5$ mixtures under the following experimental conditions: $500{ }^{\circ} \mathrm{C}, 4.9 \mathrm{MPa}, \mathrm{MPa}$, $\mathrm{H}_{2} /$ feed volume ratio of $267 \mathrm{~m}^{3} /$ $\mathrm{m}^{3}$, and LHSV of $1.3 / \mathrm{h}$ 
Fig. 12 Relative deactivation rates versus BTX yield obtained at $500{ }^{\circ} \mathrm{C}, 4.9 \mathrm{MPa}, \mathrm{H}_{2} /$ feed volume ratio of $267 \mathrm{~m}^{3} / \mathrm{m}^{3}$, and LHSV of $1.3 / \mathrm{h}$ for the materials used in this work

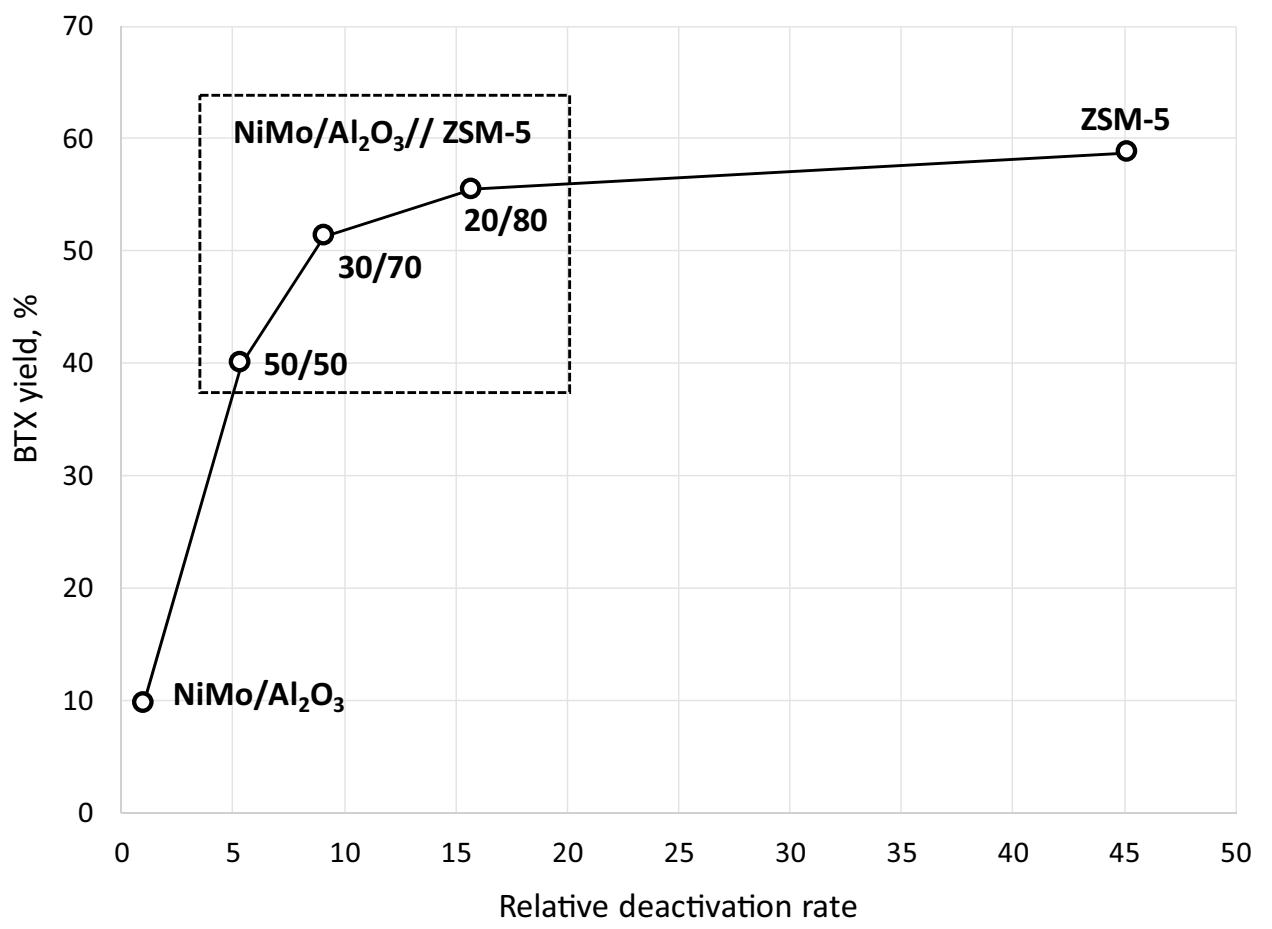

$\mathrm{NiMo} / \mathrm{Al}_{2} \mathrm{O}_{3}$ catalyst alone due to the presence of strong acid sites that induce the formation of coke precursors [2, 13]. The lack of metal moieties to reduce the presence of polynuclear aromatics certainly assists in the formation of more polymerized carbon [15].

Figure 12 was prepared for comparison purposes with the relative deactivation versus BTX yield. The catalytic systems prepared by mixing $\mathrm{NiMo} / \mathrm{Al}_{2} \mathrm{O}_{3}$ and ZSM- 5 with different amounts may still be an option to achieve high BTX yields without losing the catalyst activity under moderate experimental conditions. In summary, the wt $\%$ of ZSM-5 in the catalytic system can be optimized to get the maximum BTX yield paired to a good catalyst life.

\section{Conclusions}

A compromise between operating conditions and catalytic system is required to achieve high selectivity to BTX from the hydrogenation, cracking and hydrocracking of tetralin and a good catalyst life. The catalytic system should have a proper balance between accessible, well-dispersed and strong Brönsted acid sites required for the hydrocracking of tetralin into BTX and metal moieties to minimize deactivation by the formation of coke precursors. Mixtures of a NiMo/ $\mathrm{Al}_{2} \mathrm{O}_{3}$ catalyst with ZSM-5 were suitable to accomplish 86-95 wt\% of tetralin conversions and $44-71 \mathrm{wt} \%$ of selectivity to BTX. Due to the decrement in the liquid fraction at gas formation expenses as the ZSM-5 content increased in the $\mathrm{NiMo} / \mathrm{Al}_{2} \mathrm{O}_{3} / / Z \mathrm{ZSM}-5$ mixtures, a maximum yield of $55 \mathrm{wt} \%$ of BTX was obtained with the $20 / 80 \mathrm{NiMo} / \mathrm{Al}_{2} \mathrm{O}_{3} / / Z \mathrm{ZSM}-5$ catalytic mixture compared to the $58 \mathrm{wt} \%$ obtained with the ZSM-5 alone. However, the relative deactivation rate was considerably less important for the mixture (16 versus 45 ) than for ZSM-5 alone. Consequently, it is very important to find an optimum value in order to reduce polymerization reactions that promotes catalyst deactivation by coke formation and, therefore, maintain an appropriate BTX yield.

Acknowledgements The authors are grateful for the financial support provided by the Mexican Petroleum Institute, Mexico.

Author contribution GCL and EAB conceived and designed the experiments; AGL, RAR and VHMM performed the experiments; PPR carried out the HRTEM and TGA analysis on the catalyst and provided interpretation; GCL, PVM and PPR wrote the paper.

\section{Compliance with ethical standards}

Conflict of interest The authors declare no conflict of interest.

Open Access This article is distributed under the terms of the Creative Commons Attribution 4.0 International License (http://creativeco mmons.org/licenses/by/4.0/), which permits unrestricted use, distribution, and reproduction in any medium, provided you give appropriate credit to the original author(s) and the source, provide a link to the Creative Commons license, and indicate if changes were made. 


\section{References}

1. Ali SA (2007) Thermodynamic aspects of aromatic hydrogenation. Pet Sci Technol 25:1293-1304. https://doi.org/10.1080/10916 460500528607

2. Argyle MD, Bartholomew CH (2005) Heterogeneous catalyst regeneration and reactivation: a review. Catalyst 5:145-269. https ://doi.org/10.3390/catal5010145

3. Barzzetti T, Selli E, Moscotti D, Forni L (1996) Pyridine and ammonia as probes for FTIR analysis of solid acid catalysts. J Chem Soc Faraday Trans 92:1401-1402. https://doi.org/10.1039/ FT9969201401

4. Bounaceur R, Scacchi G, Marquaire P-M, Dominé F (2000) Mechanism modeling of the thermal cracking of tetralin. Ind Eng Chem Res 39:4152-4165. https://doi.org/10.1021/ie000276f

5. Bremmer MG, Van Haalden L, Hensen EJM, Frenken JWM, Koyman PJ (2016) Instability of NiMoS2 and CoMoS2 hydrodesulfurization catalysts at ambient conditions: a quasi in situ high-resolution transmission electron microscopy and X-ray photoelectron spectroscopy study. J Phys Chem 120:19204-19211. https://doi. org/10.1021/acs.jpcc.6b06030

6. Chon H, Woo SI, Park S-E (1996) Recent advances and new horizons in zeolite science and technology. Elsevier, New York (ISBN: 9780080543901)

7. (2017) Database of zeolite structures. https://www.iza-structure. org/databases/. Accessed 3 Oct 2019

8. Emeis CA (1993) Determination of integrated molar extinction coefficients for infrared absorption bands of pyridine adsorbed on solid acid catalysts. J Catal 14:347-354. https://doi.org/10.1006/ jcat.1993.1145

9. Environmental Protection Agency (2019) Diesel fuel standards and rulemakings. https://www.epa.gov/diesel-fuel-standards/diese 1-fuel-standards-and-rulemakings. Accessed 3 Oct 2019

10. European Automobile Manufacturers Association (2019) Worldwide fuel charter-ACEA. https://fliphtml5.com/twsl/iert. Accessed 3 Oct 2019

11. Ferraz SGA, Zanon-Zotin FM, Radi-Araujo LR, Zotin JL (2010) Influence of support acidity of NiMoS catalysts in the activity for hydrogenation and hydrocracking of tetralin. Appl Catal A 384:51-57. https://doi.org/10.1016/j.apcata.2010.06.003

12. Fogler HS (2006) Catalyst decay. In: Elements of chemical reactor engineering, 4th edn. Prentice Hall International Series (ISBN-13: 978-0130473943)

13. Guisnet M, Costa L, Ramoa-Ribeiro R (2009) Prevention of zeolite deactivation by coking. J Mol Catal A Chem 305:69-83. https ://doi.org/10.1016/j.molcata.2008.11.012

14. Laredo GC, Figueroa Y, Cano JL, Mares MT, Castillo J (2002) Estudio de la composición del aceite cíclico ligero provenientes de crudos mexicanos. J Mex Chem Soc 46:115-119
15. Laredo GC, Pérez-Romo P, Escobar J, García-Gutiérrez JL, VegaMerino PM (2017) Light cycle oil upgrading to benzene, toluene and xylenes by hydrocracking: studies using model mixtures. Ind Eng Chem Res 56:10939-10948. https://doi.org/10.1021/acs. iecr.7b02827

16. Lee J, Choi Y, Shin J, Lee JK (2016) Selective hydrocracking of tetralin for light aromatic hydrocarbons. Catal Today 265:144153. https://doi.org/10.1016/j.cattod.2015.09.046

17. Matsushita K, Hauser A, Marafi A, Koide R, Stanislaus A (2004) Initial coke deposition on hydrotreating catalysts. Part 1. Changes in coke properties as a function of time on stream. Fuel 83:10311038. https://doi.org/10.1016/j.fuel.2003.10.015

18. Sato K, Iwata Y, Yoneda T, Nishijima A, Miki Y, Shimada H (1998) Hydrocracking of diphenylmethane and tetralin over bifunctional NiW sulfide catalyst supported in three types of zeolites. Catal Today 45:367-374. https://doi.org/10.1016/S0920 -5861(98)00266-1

19. Sato K, Iwata Y, Miki Y, Shimada H (1999) Hydrocracking of tetralin over NiW/USY zeolite catalyst for the improvement of heavy oils upgrading catalyst. J Catal 186:45-56. https://doi. org/10.1006/jcat.1999.2546

20. Shin J, Oh Y, Choi Y, Lee J, Lee JK (2017) Design of selective hydrocracking catalyst for BTX production from diesel-boilingrange polycyclic aromatic hydrocarbons. Appl Catal 547:12-21. https://doi.org/10.1016/j.apcata.2017.08.019

21. Stanislaus A, Marafi A, Rana MS (2010) Recent advances in the science and technology of ultra-low sulfur diesel (ULSD) production. Catal Today 153:1-68. https://doi.org/10.1016/j.catto d.2010.05.011

22. Townsend AT, Abbot J (1992) Catalytic reactions of tetralin on HY zeolite. Appl Catal A 90:97-115. https://doi.org/10.1016/0926$860 X(92) 85051-\mathrm{C}$

23. Townsend AT, Abbot J (1993) Catalytic reactions of tetralin on HZSM-5 zeolite. Appl Catal A 95:221-236. https://doi. org/10.1016/0926-860X(93)85076-2

24. Tsai T-C, Lin S-B, Wang I (1999) Disproportionation and transalkylation of alkylbenzenes over zeolite catalyst. Appl Catal A Gral 181:355-398. https://doi.org/10.1016/S0926 $-860 X(98) 00396-2$

25. Upare DP, Park S, Kim MS, Kim J, Lee D, Lee J, Chang H, Choi W, Choi S, Jeon YP (2016) Cobalt promoted Mo/beta zeolite for selective hydrocracking of tetralin and pyrolysis fuel oil into monocyclic aromatic hydrocarbons. J Ind Eng Chem 35:99-107. https://doi.org/10.1016/j.jiec.2015.12.020

Publisher's Note Springer Nature remains neutral with regard to jurisdictional claims in published maps and institutional affiliations. 